\title{
Audit Delay of Listed Companies: A Case of Malaysia
}

\author{
Ayoib Che-Ahmad \\ College of Business, Universiti Utara Malaysia \\ 06010 UUM Sintok, Kedah, Malaysia \\ Tel: 60-4-928-3942 E-mail: ayoib@uum.edu.my \\ Shamharir Abidin \\ College of Business, Universiti Utara Malaysia \\ 06010 UUM Sintok, Kedah, Malaysia \\ Tel: 60-4-928-3943_E-mail: sham1202@uum.edu.my
}

\begin{abstract}
It is important to understand factors that influence audit delay since it directly affects the timeliness of financial reporting which is one of the most important qualitative attributes of financial statements (Ashton et. al., 1987; Carslaw \& Kaplan, 1991; and Johnson, 1998). A number of studies have investigated audit market research including the issue surrounding audit delay within the context of developed countries. However, audit market research in the developing countries is very limited despite calls in the literature to expand the scope of market studies to those nations (see for example, Simon et al. 1992; Walker and Johnson 1996; Che-Ahmad and Houghton 1996; Taylor 1997). This study extends previous research by examining the determinants of audit delay in a developing country. Malaysia is one such country that provides a rich setting for audit market research. It seeks to provide empirical evidence concerning audit delay of Malaysian public listed companies.

The findings indicated that the mean audit delay of Malaysian companies to be much longer than the delay in Western countries. The multivariate analysis showed that director shareholdings, total assets, number of subsidiaries, type of audit firms, audit opinion and return on equity to be important determinants of audit delay. The regression results for non-banking and finance sectors were very similar. However, only director shareholding variable was found to be strongly significant in banking and finance sub-sample suggesting the importance of ownership structure in influencing audit lag in this sector. The differences in regulatory framework for both sectors could be a significant reason for the differences in the findings and warrant further research.
\end{abstract}

Keywords: Audit Delay, Audit Report, Malaysia

\section{Introduction}

The importance of timely financial reporting by corporate entities is of interest to policymakers. In the United States, Financial Accounting Standard Board (FASB), for example addresses its importance in the Statement of Financial Accounting Concepts No. 2 as an "ancillary aspect" of relevance. The statement also suggests that "a lack of timeliness can rob information of relevance it might otherwise have had" (paragraph 56, FASB, 1980). In Malaysia, the Bursa Malaysia (Malaysia Bourse) demands timely financial reporting through the provision of Chapter 2 (2.03-2) and Chapter 9 (9.01-3) of the Listing Requirements of Bursa Malaysia Securities Berhad.

Previous studies have examined the issues of timeliness of information from different angles. Ashton, Willingham and Elliott (1987, p. 275) contended that “... the timeliness of information release can affect the level of uncertainty associated with decisions based on the reported information." Feltham's (1972) analytical model shows that a decision-maker's action choices and expected payoff are affected significantly by the timeliness of information release. Further, Givoly and Palmon (1982) and Kross and Schroeder (1984) found that delayed announcements of earnings are associated with lower abnormal returns than those of timely announcements. They also concluded that the timing of such announcements is significantly affected by the lag of audit report, i.e. the length of time from a company's financial year-end to the date of auditor's report (Ashton et al., 1987; Carslaw \& Kaplan, 1991; and Johnson, 1998).

While a number of researchers have investigated the issue surrounding audit delay within the context of advanced countries, little has been done to investigate the same issue in developing countries. This is especially true in the case of 
countries with new capital markets and regulatory enforcements. This is continuing despite calls in the literature to expand the scope of market studies to those nations (see for example, Simon et al. 1992; Walker and Johnson 1996; Che-Ahmad and Houghton 1996; Taylor 1997). Further, Newton and Ashton (1989) suggested that a more refined analysis is needed to understand the cause of audit delay especially in different industries. Bamber et al. (1993) added a variable that classified companies into two namely financial and non-financial companies. They contended that financial sector represents a less complex auditee and therefore should experience shorter audit delay. It is also well known that financial companies are subject to different regulation and acts and are monitored closely by the regulators. The primary purpose of this study is to provide empirical evidence concerning audit delay of publicly listed Malaysian companies. Specifically, this study investigates factors that could influence the timeliness of annual reports and provides further evidence on the effect of client industry (i.e. financial vs. non-financial) on audit delay.

The remainder of this paper is structured as follows. The next section provides the background to regulatory requirements concerning financial reporting timeliness by critically reviewing prior studies. The third section considers the research design employed for this study. The fourth section discusses the empirical results. The final section suggests possible limitations of the paper and concludes the study.

\section{Background and Prior Studies}

The Malaysian Companies Acts 1965 requires the accounts of all public companies to be audited by a qualified accountant. In addition, the Bursa Malaysia also requires companies to comply with Chapter 9 the Listing Requirement. This section stipulates that the interval between the close of the financial year of the company and the issue of the printed annual report to the company's shareholders and the exchange shall not exceed six months. Companies breaching this section can be publicly reprimanded. The Bursa Malaysia views the delay of issuing audited annual report seriously and cautions directors of the companies about their responsibility to maintain appropriate standards of corporate responsibility and accountability. The delay of the report to be furnished to company's shareholders is of interest since it has a close association with the audit functions. This is because the financial statements cannot be issued until an audit has been duly performed and concluded (Johnson, 1998).

Weygandt, Kieso and Kimmel (1998, p. 518) explained that financial information is relevant to users if it can influence or make a difference to their decision. For the information to be relevant it must be timely, i.e. it must be available before it looses its capacity to influence a user's decisions. Ashton et al. (1987) examined a sample of 488 companies that were Peat Marwick Mitchell \& Co, US clients for 1981. Using 14 variables (some of which are not publicly available), they found that the length of audit delay is significantly longer for companies that i) are categorized as nonfinancial, ii) have received qualified audit opinion, iii) have a fiscal year-end in December, iv) are non-listed companies, v) have poor internal controls, vi) rely on less complex data-processing technology, and vii) have a greater relative amount of audit work performed after year-end. Overall, the mean audit delay for the sample was reported at 62.5 days.

Ashton, Graul and Newton (1989) found that mean audit delays are associated with the type of industry, in that the financial clients have been found to have a shorter audit delay than the non-financial clients. This finding is consistent with Ashton et al. (1987). Ashton et al. (1989) also found that longer audit delay has a positive relationship with financial losses and the existence of extraordinary items. Surprisingly, Ashton et al. (1989) found that clean audit opinions were associated with longer audit delay. Although, the result is contrary to Ashton et al. (1987), they did not offer any explanation for the unexpected result.

Newton and Ashton (1989) studied the relationship between audit delay and audit firm structure for 300 Canadian firms. They found that longer audit delay was significantly associated with smaller clients, non-financial clients, existence of extraordinary items and structured audit firms. On average, the delay of audit report was recorded at 54 days. Carslaw and Kaplan (1991) examined New Zealand public listed companies using a model that is based on Ashton et. al (1987). In the study, they tested two hypothesis variables, namely, company ownership and debt proportion. Although the results were in the predicted directions for both variables, the results were not consistent for different datasets in terms of statistical significance. Debt proportion for example, was significant in 1988 but not in 1987 . With respect to company ownership, a significant effect was only found for 1987, but not in 1988 .

Whittred (1980) examined the effect of audit qualification on the timeliness of corporate annual report by using a univariate relationship test approach. The result of the study indicated that "first time" qualifications delay the release of companies' preliminary profit and the distribution of corporate annual report. This is due to an increase in the year-end time taken to complete the audit and also an increase in auditor-client negotiation time as a result of impending qualification. In general, the study concluded that "... the more serious the qualification, the greater the delay" (Whittred, 1980, p. 576).

\section{Research Design}

The sample considered in this study consists of all publicly held Malaysian companies, which were listed on both the 
Main Board and the Second Board of the Bursa Malaysia (formerly known as Kuala Lumpur Stock Exchange), as at 31 December 1993. Data are extracted from corporate annual reports with the financial year ending in the same year. The year 1993 was chosen since the economic and political environments were stable during the period.

Analysis of the dataset was conducted using the following model of audit delay. The model is replicated and extended from the one employed by Carslaw and Kaplan (1991).

\section{LDELAY $=\alpha+\beta_{1}$ FIN $+\beta_{2}$ LASSET $+\beta_{3}$ LSUBS $+\beta_{4}$ INVREC $+\beta_{5}$ LEV $+\beta_{6}$ ROE + $\beta_{7}$ DIRSH $+\beta_{8}$ BSIX $+\beta_{9}$ BUSY $+\beta_{10}$ COPINION $+\beta_{11}$ CHANGE $+\varepsilon$}

Where (expected sign in parenthesis):

\begin{tabular}{|c|c|}
\hline DELAY & $\begin{array}{l}=\log _{10} \text { of number of days from the financial year-end to the date of audit } \\
\text { report. }\end{array}$ \\
\hline FIN (-) & $\begin{array}{l}=\text { Industry classification represented by a dummy variable: " } 1 \text { " for } \\
\text { financial (banks, finance, insurance, and securities and investment } \\
\text { sectors) and " } 0 \text { " for non-financial companies. }\end{array}$ \\
\hline LASSET (-) & $=\log _{10}$ total assets of company as a proxy to measure company size \\
\hline LSUBS $(+)$ & $=\log _{10}$ number of subsidiaries +1 (including the holding company) \\
\hline $\operatorname{INVREC~}(+)$ & $\begin{array}{l}=\text { Total of inventory and receivables divided by total assets. Note that for } \\
\text { financial companies, this includes trade bills, bills receivables, advances } \\
\text { to customers and lendings. }\end{array}$ \\
\hline $\operatorname{LEV}(+)$ & $=$ Proportion of long-term debt (excluding deferred tax) to total equity. \\
\hline ROE (-) & $=$ Proportion of net profit to shareholders' equity \\
\hline DIRSH (+) & $\begin{array}{l}=\text { Ratio of client's directors' shareholding (based on the number of } \\
\text { common shares held by the directors divided by the total number of } \\
\text { common share outstanding). }\end{array}$ \\
\hline BSIX (-) & $\begin{array}{l}=\text { Type of company auditor, represented by a dummy variable: " } 1 \text { " for the } \\
\text { Big-Six auditors and " } 0 \text { " for others. }\end{array}$ \\
\hline BUSY $(+)$ & $\begin{aligned}= & \text { A dummy variable coded " } 1 \text { " for companies with financial year date } \\
& \text { between } 31 \text { December to } 31 \text { March, "0" otherwise. }\end{aligned}$ \\
\hline COPINION $(+)$ & $\begin{array}{l}=\text { Audit opinion issued by auditor, represented by a dummy variable: " } 1 \text { " } \\
\text { for companies with qualified opinion and " } 0 \text { " for those with unqualified } \\
\text { opinion. }\end{array}$ \\
\hline CHANGE $(+)$ & $\begin{array}{l}=\text { A dummy variable coded " } 1 \text { " if the incumbent auditor is a new auditor } \\
\text { and " } 0 \text { " otherwise. }\end{array}$ \\
\hline & Error term assumed to be normally distributed with constant variance. \\
\hline
\end{tabular}

\subsection{Variable discussion}

Unique aspects of different industries are likely to affect the relative length of time to complete an audit. Financial companies are expected to experience shorter audit delay due to the fact that such companies have little or no inventory (Ashton et. al. 1989; Carslaw and Kaplan, 1991). In addition, the accounting systems of the financial services industry are generally highly centralized and automated (Bamber et. al. 1993). In the case of Malaysia, it was found that more than $70 \%$ of financial companies depend heavily on computer in their day-to-day operations (Basariah, Mahamad and Shamharir, 2000). These two facts (i.e. less inventories and highly automated system) reduce the audit coverage as the inventory segment represents the most difficult area to audit (Carslaw and Kaplan, 1991) and the centralized and automated accounting systems mean less diverse transactions. In addition, the banking industry is also governed separately by the Bank Negara (Central Bank).

Another important determinant of audit delay is company size. Normally, total assets have been used to measure size of company in previous studies of audit delay. The variable was found to have a negative relationship with audit delay (see for example, Carslaw and Kaplan, 1991; and Newton and Ashton, 1989). It was contended that several factors account for this relationship. For example, it is commonly known that big companies normally have reliable internal control, which in turn would reduce the propensity for financial statement error. Hence, auditors are likely to rely more on the 
client's internal control, which in turn will reduce the extent of audit substantive test.

Similar relationship is expected between complexities of the companies and timeliness of financial reporting. Due to a client's diversified business operations, an auditor of a client-company with a large number of subsidiaries is expected to utilize additional time. It is expected that as complexity of the client increases, the auditor will spend more time to complete the audit task.

Another measure of complexity is the ratio of inventory and receivables to total assets. The variable should be positively related to audit delay. A larger proportion of receivables and inventory requires more audit effort for verification of balances in the balance sheet and hence a need for longer time.

Carslaw and Kaplan (1991) suggested that auditing of a company with a high proportion of debt to assets consumes more time than a company with a relatively low proportion of debt. One of the reasons is the fact that a company with a high proportion of debt to total assets tends to be associated with financial distress and ultimately the greater likelihood of bankruptcy. In this study, the proportion of long-term debt (excluding deferred tax) to total equity is included in the model. The amount of long-term debt may also raise the agency costs as suggested by Jensen and Meckling (1976) and this is likely to increase the audit efforts and hence, the length of the audit engagement.

The auditor is likely to perform his audit task more cautiously if the profitability of the client is low due to higher business risk. As the auditor performs the audit cautiously and thoroughly, the audit delay is expected to be longer as compared with the audit of companies with higher profitability. ROE is used to proxy for profitability in this study.

Audit delay literature (see for example, Ashton, et al. 1987; Carslaw and Kaplan, 1991; and Bambers et al. 1993) suggests that companies with a high level of manager ownership are likely to experience longer lag due to less pressure for timely information release. This is because the owner managers already have easy access to the information.

The size of audit firms is likely to affect audit delay. Large audit firms have a greater propensity to complete audits in a shorter time due to their greater resources compared with smaller firms (Carslaw and Kaplan, 1991). These firms are likely to develop audit specialization and expertise in certain areas and industries, which in turn will result in audit works being performed more efficiently. Following previous studies, a dichotomous variable is used to identify large audit firms (previously defined as Big Six, but now Big Four auditors).

A company that has a financial year-end similar to the others is expected to experience longer audit delay. This is due to the fact that a large number of audits with the same financial year-end date may cause scheduling problems for the auditor (Carslaw and Kaplan, 1991) and also a shortage in audit personnel to be assigned in each audit engagements.

Bamber et al. (1993) argued that the qualified opinions are not likely to be issued until the auditor has spent considerable time and effort in performing additional audit procedures. Moreover, companies always view audit qualified opinion as "bad news" and might not respond to the auditor's request promptly. It is a symptom of auditor-management conflict that would also increase audit delay (Carslaw and Kaplan, 1991).

Similar relationship is expected when companies change their auditor. The new auditor is likely to spend more time on audit work in order to study and understand their new clients compared with existing clients.

\section{Results}

There were 413 companies listed on the Bursa Malaysia as of 31 December 1993. However, after excluding several companies for various reasons, only 343 companies were selected to form the final sample. (Note 1)

The next section reports the descriptive statistics related to the sample companies followed by a section that explains the results of the multivariate test. Further, we provide additional tests by splitting the sample into two sub-samples namely, financial companies and non-financial companies.

\subsection{Descriptive statistics}

Table 1 shows the descriptive statistics for sample companies during the period under study. The mean audit delay was 114 days with a minimum delay of 20 days. The longest delay was reported to be 442 days. Only nine companies were found to have audit lag of more than 180 days and this might violate the Bursa Malaysia rule with regards to the minimum submission period of six months. Compared with the delays in other countries, namely, the USA; 62.5 days (Ashton et al., 1987), Canada; 54 days (Newton and Ashton, 1989) and New Zealand; 87.7 days (Carslaw and Kaplan, 1991), the mean period of audit delay for Malaysian companies seems to be longer. Part of the reason could be due to lack of auditors in Malaysia and/or perhaps weak enforcement from the regulatory bodies. Meanwhile, the mean total asset was MYR1.14 billions with the standard deviation of about MYR3.81 billions.

As expected, the Big-Six audit firms were dominant in the Malaysian audit market for public listed companies. The market-share of these "first-tier firms" was reported to be $77.3 \%$, leaving less than $25 \%$ of companies to the non Big-Six firms. More than $70 \%$ of the companies were audited during the busy season, i.e. December through May. Meanwhile only $4.1 \%$ of the companies changed their auditor in 1993 and the same percentage of companies was 
reported to receive qualified audit opinion.

\subsection{Multivariate results}

To investigate the multivariate relationship between independent and dependent variables, we performed an OLS regression. Following the method of previous studies, audit delay, total assets and numbers of subsidiaries were transformed using the natural log function. Table 2 exhibits the regression results for all variables. (Note 2)

Six out of eleven independent variables were significantly associated with LDELAY in the predicted directions. Four variables (LASSET, DIRSH, LSUBS and ROE) were highly significant at the one-percent level. Large companies tend to have strong internal control systems that are relied upon by auditors and this is reflected by less audit work. Similarly, less profitable companies are more risky and need additional audit work. The same can be said for complex companies that need additional scrutiny. As expected, the higher the directors' interest in the company, the higher the audit delay. This is because timely financial reports are less crucial for companies with high director shareholdings since the directors are likely to have easy access to the company information. The result is consistent with that of Carslaw and Kaplan (1991). COPINION and BSIX were significant at the five-percent significance level. (Note 3) As indicated earlier, auditors need more time to audit companies that are issued qualified opinions. As expected large audit firms (BSIX) were associated with less audit delay. This may be due to greater resources owned by large firms such as adequate qualified staff that reduce the time taken to complete the audit works. Although the direction of the association between FIN variable and the delay is as expected, the model however, shows no significant relationship between financial companies and the audit delay. Note that the model $\mathrm{R}^{2}$ is $19.5 \%$ and the F-Ratio is significant at less than one-percent. (Note 4)

\subsection{Financial and non-Financial Companies}

To provide further evidence on the role of FIN on audit delay, we split the sample into two sub-samples and performed multiple regressions on each sample. Table 3 below presents the descriptive statistics of the non-financial and financial subsamples. The mean audit delay of 105.97 days of the financial sector is approximately a week shorter than that of the non-financial subsample. Financial subsample companies were found to own more assets as well as greater ROE. The Big Six audited $72 \%$ of the financial companies and $78 \%$ of non-financial companies while $82 \%$ of the financial companies were audited during the busy season as opposed to $69 \%$ in the non-financial sector. Additionally, the non-financial companies have recorded fewer inventories and receivables as well as fewer ROE. They also received fewer qualified audit opinions and experienced fewer auditor changes.

Table 4 exhibits the results of OLS regressions of the two subsamples. For the non-financial subsample, the six variables that significantly affected audit delay in the overall sample were also significantly affected audit delay during the year under study in the predicted directions. In fact, the results were identical to the results of the full sample in terms of statistical significance. Note that the $\mathrm{R}^{2}$ is about $20 \%$ and the F-ratio is significant at less than one-percent significant level.

On the other hand, the result for the financial subsample is somewhat different. Except for DIRSH, LSUBS and COPINION, the other variables were no longer significantly associated with audit delay. Only DIRSH was statistically significant at the one percent level while LSUBS and COPINION were weakly significant at the ten-percent level. Interestingly, the $\mathrm{R}^{2}$ is relatively high with about $28 \%$ of the variations are explained by the model. The F-ratio is also significant at less than four percent. The results suggest that there may be other variables that are not incorporated in the model for financial companies and that may have resulted in omitted variable errors. As well, the differences in regulatory framework for both subsamples could be one reason for the differences in the findings and this warrant further research.

\section{Conclusions}

The present study has sought to explain the determinants of audit delay in a Malaysian environment. The results were broadly consistent with previous studies done in Western countries. Size, complexities, directors' shareholdings, the size of auditor, audit opinion and the profitability of the companies are the major determinants of audit delay. The same results were also found in non-banking and finance sector. However, only directors' shareholdings was found to be significantly associated with audit delay at a one-percent significant level while client complexities and audit opinion were significant at the ten-percent level. Differences in regulatory framework were offered as one of the possible causes for the differences.

There are possible limitations to the design described in this study, especially regarding the measurement of directors' interest. The interests of the directors are disclosed in the director's report. However, the data may not reflect the accurate percentage of ownership as both direct and indirect shareholdings are included in total interests in many cases. Furthermore, the presence of institutional shareholders and the use of nominee companies to register shareholdings may also add noise to the analysis. However, the new amendments to the Companies Act 1965 provide clear definitions of what constitutes the "interest(s) in shares" (Cheong, 1990). Substantial penalties imposed for nondisclosure or 
inaccurate financial disclosures are likely to minimise the inaccuracy of the data.

\section{References}

Ashton, R., J. Willingham, and R. Elliott, (1987) Empirical Analysis of Audit Delay. Journal of Accounting Research (autumn). pp. 275-292.

Ashton, R., P. Graul, and J. Newton. (1989) Audit Delay and the Timeliness of Corporate Reporting. Contemporary Accounting Research (Spring). pp. 657-673.

Bamber ,E., L. Bamber, and M. Schoderboek. (1993) Audit Structure and Other Determinants of Audit Report Lag: an Empirical Analysis. Auditing: A Journal of Practice \& Theory, 11(1): pp 1-23.

Basariah, S, T. Mahamad, and A. Shamharir (2000) Computer Crime and Security: A Survey of Financial Institutions in Malaysia, Paper Presented at Seminar on Accounting and Information Technology, 13 - 14 November 2000, Convention Centre, Universiti Utara Malaysia.

Carslaw, C. and S. Kaplan. (1991). An Examination of Audit Delay: Further Evidence from New Zealand. Accounting and Business Research (Winter). pp. 21-32.

Che-Ahmad, A. and K.A. Houghton. (1996). Audit Fee Premiums to Big Eight Firms: Evidence from the Medium-Size UK Auditees. Journal of International Accounting, Auditing and Taxation, 5(1): pp. 53-72.

Cheong, S. (1990). Corporate Groupings in the KLSE. Petaling Jaya, Malaysia: Modern Law Publishers \& Distributors.

Cook, R. D. and S. Weisberg. (1982). Residuals and Influence in Regression. New York: Chapman \& Hall.

Financial Accounting Standards Board. (1980). Statement of Financial Accounting Concepts No. 2, Qualitative Characteristics of Accounting Information. Stanford, CT: FASB.

Feltham, G.A. Information Evaluation. Studies in Accounting Research, no. 5, Sarasota, Fla,: American Accounting Assn., 1972.

Givoly, D., and Palmon. (1982) Timeliness of Annual Earnings Announcements: Some Empirical Evidence. The Accounting Review (July). pp. 486-508.

Jensen, M. C. and W. H. Meckling. (1976). Theory of the Firm: Managerial Behavior, Agency Costs and Ownership Structure. Journal of Financial Economics, 3(4), (October): 305-360.

Johnson, L, E. Further Evidence on the Determinants of Local Government Audit Delay. (1998). Journal of Public Budgeting, Accounting and Financial Management, 10(3), pp. 375-379.

Kross, W., and D.A. Schroeder (1984). An Empirical Investigation Of The Effect Of Quarterly Earnings Announcement Timing On Stock Returns. Journal of Accounting Research (Spring). pp. 153-76.

Newton, J. and R. Ashton. (1989). The Association Between Audit Technology and Audit Delay. Auditing: A Journal of Practice and Theory (Supplement). pp. 20-37.

Ramsey, J. B. (1969). Tests For Specification Error In Classical Linear Least Squares Regression Analysis. Journal of the Royal Statistical Society. Series B 31, pp. 350-371.

Simon, D.T., S. Teo and G. Trompeter. (1992). A Comparative Study of the Market for Audit Services in Hong Kong, Malaysia and Singapore, International Journal of Accounting, 27: pp. 234-240.

Taylor, M.H. (1997). The Market for Audit Services in Japan, Pacific Accounting Review, 9(2): pp. 59-74.

Walker, K.B. and E.N. Johnson. (1996). A Review and Synthesis of Research on Supplier Concentration, Quality and Fee Structure in Non-U.S. Markets for Auditor Services, International Journal of Accounting, 31 (1): pp. 1-18.

Weigandt, Kieso and Kimmel. (1998) Accounting Principles, $5^{\text {th }}$ ed., John Wiley and Sons , Inc.

Whittred, G. (1980). Audit Qualification and the Timeliness of Corporate Annual Reports. The Accounting Review (October), pp 563-577.

\section{Notes}

Note 1 . Out of 70 companies excluded, 44 were newly listed companies, 15 changed the corporate financial year-end, one company was under suspension from the Bursa Malaysia, and 11 companies did not have sufficient data for the study.

Note 2. The (robust) results were corrected for heteroscedasticity based on the method of Cook and Weisberg (1993). Note that the results were almost identical to the (uncorrected) original regression results in terms of significant variables and the signs of variables. The R-squared and the F-Statistics were also similar. The regression specification error test (Ramsey, 1969) indicated no specification problem. 
Note 3. The variables Inflation Factor (VIF) for all variables were not more that 2.5 and were not likely to pose a multicollinearity problem. However, since LSUBS and LASSET were found to be correlated with 0.55 and significant (1-tailed) at $1 \%$, additional regressions were carried out by first dropping the variable LASSET and then the variables LSUBS. The results suggested that there was no change in signs, size or significant levels of the remaining variables. Hence, multicollinearity should not pose any problem in interpreting the results.

Note 4 . The robust estimate of the regression results using STATA statistical software did not produce adjusted $\mathrm{R}^{2}$.

Table 1. Descriptive statistics for the dependent and variables $(\mathrm{n}=343)$

\begin{tabular}{|l|r|r|c|}
\hline \multicolumn{1}{|c|}{ Variable } & \multicolumn{1}{c|}{ Mean } & \multicolumn{1}{c|}{ SD } & \% \\
\hline AUDIT DELAY (days) & 114.45 & 39.06 & \\
\hline TOTAL ASSETS* & $1,135,707.74$ & $3,808,087.57$ & \\
\hline DIRSH & 0.36 & 0.36 & \\
\hline LEV & 0.07 & 0.09 & \\
\hline LSUBS & 0.93 & 0.52 & \\
\hline INVREC & 0.29 & 0.23 & \\
\hline ROE & 0.25 & 0.33 & \\
\hline FIN & & & 11.40 \\
\hline COPINION & & & 4.10 \\
\hline BSIX & & & 77.30 \\
\hline BUSY & & & 70.30 \\
\hline CHANGE & & & 4.10 \\
\hline
\end{tabular}

*The figure is stated in RM ' 000

Table 2. Results of OLS Regression (Robust) for 1993 ( $n=343$ )

\begin{tabular}{|l|c|r|c|rl|}
\hline Variable & $\begin{array}{c}\text { Expected } \\
\text { Sign }\end{array}$ & Coef. & $\begin{array}{c}\text { Robust } \\
\text { Std. Error }\end{array}$ & t-statistics \\
\hline FIN & - & -0.005 & 0.039 & -0.123 & \\
\hline LASSET & - & -0.058 & 0.019 & -3.074 & \\
\hline LSUBS & + & 0.061 & 0.020 & $3.020 \quad * * *$ \\
\hline INVREC & + & -0.021 & 0.038 & -0.535 & \\
\hline LEV & + & -0.013 & 0.081 & -0.155 & \\
\hline ROE & - & -0.075 & 0.022 & $-3.408 \quad * * *$ \\
\hline DIRSH & + & 0.073 & 0.022 & $3.375 \quad * * *$ \\
\hline BSIX & - & -0.033 & 0.017 & -1.944 & \\
\hline BUSY & + & 0.003 & 0.016 & 0.170 & \\
\hline COPINION & + & 0.077 & 0.036 & $2.130 \quad * *$ \\
\hline CHANGE & + & 0.038 & 0.039 & 0.989 & \\
\hline Constant & $+/-$ & 2.311 & 0.098 & $23.501 \quad * * *$ \\
\hline F-ratio & $9.00^{* * *}$ & & & \\
\hline R-squared & 0.195 & & & \\
\hline
\end{tabular}

*** Significant at 1 percent level (one-tailed where signs are expected, two-tailed otherwise)

** Significant at 5 percent level (one-tailed where signs are expected, two-tailed otherwise)

* Significant at 10 percent level (one-tailed where signs are expected, two-tailed otherwise) 
Table 3. Descriptive statistics for the dependent and explanatory variables for the non-financial and financial subsamples

\begin{tabular}{|l|r|r|r|r|r|r|}
\hline & \multicolumn{2}{|c|}{ Non-Financial Sector $(\mathrm{n}=304)$} & \multicolumn{3}{|c|}{ Financial Sector $(\mathrm{n}=39)$} \\
\hline Variable & \multicolumn{1}{c|}{ Mean } & \multicolumn{1}{c|}{ SD } & \multicolumn{1}{c|}{$\%$} & \multicolumn{1}{c|}{ Mean } & \multicolumn{1}{c|}{ SD } & $\%$ \\
\hline AUDIT DELAY (days) & 115.53 & 38.01 & & 105.97 & 46.09 & \\
\hline TOTAL ASSET* & $658,318.97$ & $1,670,070.48$ & & $4,856,892.00$ & $9,604,128.29$ & \\
\hline DIRSH & 0.37 & 0.38 & & 0.27 & 0.29 & \\
\hline LEV & 0.07 & 0.09 & & 0.07 & 0.11 & \\
\hline LSUBS & 0.94 & 0.51 & & 0.90 & 0.53 & \\
\hline INVREC & 0.29 & 0.20 & & 0.32 & 0.39 & \\
\hline ROE & 0.23 & 0.31 & & 0.39 & 0.45 & \\
\hline COPINION & & & 3.95 & & & 5.00 \\
\hline BSIX & & & 78.00 & & & 72.00 \\
\hline BUSY & & & 69.00 & & & 82.00 \\
\hline CHANGE & & 4.00 & & & 5.00 \\
\hline
\end{tabular}

*The figure is stated in RM ' 000

Table 4. Results of OLS Regression (Robust) for the non-financial and financial subsamples

\begin{tabular}{|c|c|c|c|c|c|c|c|c|}
\hline & \multicolumn{4}{|c|}{ Non-Financial $(\mathrm{n}=304)$} & \multicolumn{4}{|c|}{ Financial $(\mathrm{n}=39)$} \\
\hline Variable & Coefficient & $\begin{array}{c}\text { Robust } \\
\text { Std.Error }\end{array}$ & \multicolumn{2}{|l|}{ t-statistics } & Coefficient & $\begin{array}{l}\text { Robust } \\
\text { Std.Error }\end{array}$ & \multicolumn{2}{|l|}{ t-statistics } \\
\hline DIRSH & 0.055 & 0.021 & $2.594 *$ & $* * *$ & 0.285 & 0.101 & 2.822 & $* * *$ \\
\hline LASSET & -0.061 & 0.018 & $-3.376 *$ & $* * *$ & -0.022 & 0.082 & -0.264 & \\
\hline LSUBS & 0.048 & 0.019 & $2.523 *$ & $* * *$ & 0.137 & 0.101 & 1.355 & * \\
\hline INVREC & -0.025 & 0.038 & -0.653 & & 0.019 & 0.122 & 0.156 & \\
\hline LEV & 0.010 & 0.090 & 0.112 & & -0.023 & 0.307 & -0.073 & \\
\hline ROE & -0.085 & 0.022 & $-3.855 *$ & $* * *$ & -0.052 & 0.111 & -0.466 & \\
\hline BSIX & -0.038 & 0.017 & $-2.159 *$ & ** & 0.050 & 0.111 & 0.453 & \\
\hline BUSY & -0.003 & 0.016 & -0.167 & & 0.033 & 0.112 & 0.294 & \\
\hline COPINION & 0.069 & 0.038 & $1.821 *$ & ** & 0.205 & 0.134 & 1.529 & * \\
\hline CHANGE & 0.038 & 0.040 & 0.950 & & -0.033 & 0.161 & -0.202 & \\
\hline Constant & 2.355 & 0.090 & $26.165 *$ & $* * *$ & 0.848 & 0.528 & 3.498 & *** \\
\hline F-ratio & \multicolumn{4}{|l|}{$9.06 * * *$} & \multicolumn{4}{|l|}{$2.00 * *$} \\
\hline$R$-squared & \multicolumn{4}{|l|}{0.200} & \multicolumn{4}{|l|}{0.282} \\
\hline
\end{tabular}

Significant at 1 percent level (one-tailed where signs are expected, two-tailed otherwise)

** Significant at 5 percent level (one-tailed where signs are expected, two-tailed otherwise)

* Significant at 10 percent level (one-tailed where signs are expected, two-tailed otherwise) 